\title{
EFEK PENAMBAHAN EVAPORATOR PADA ATMOSPHERE WATER HARVESTER (AWH) TERHADAP PERFORMA SISTEM
}

\author{
Juli Mrihardjono $^{1)}$, Didik Ariwibowo ${ }^{1}$, Sutrisno $^{1)}$, Dista Yoel Tadeus ${ }^{2\}}$ \\ ${ }^{1)}$ Program Studi S.Tr. Rekayasa Perancangan Mekanik, Sekolah Vokasi, Universitas Diponegoro \\ Jl. Prof. Soedarto, SH, Kampus Undip Tembalang, Semarang, Indonesia 50275 \\ ${ }^{2)}$ Program Studi S.Tr. Teknologi Rekayasa Otomasi, Sekolah Vokasi, Universitas Diponegoro \\ Jl. Prof. Soedarto, SH, Kampus Undip Tembalang, Semarang, Indonesia 50275
}

\begin{abstract}
Atmosphere Water Harvester (AWH) was investigated to get water collected from air in elevated performance. Improvement was performed by introducing a series-arrangement of two evaporators. Air flew through the evaporators in cross-flow. This arrangement would influence performance of the AWH system in title of $C O P, M H I$, and specific energy consumption. The AWH was designed using vapor compression refrigeration system. Parameter measured to the system were refrigerant temperature in suction and discharge line, inlet and outlet pipe wall temperatures at evaporator and condenser, air velocity enter into evaporator, and electrical energy consumption. Instrument used in this research were refrigerant pressure-temperature gauge, $K$-type digital thermometer, digital fan anemometer, thermo-hygro meter, and kWh meter. Air temperature and RH data were $36,5^{\circ} \mathrm{C}, 40 \%$, and $19{ }^{\circ} \mathrm{C}, 42 \%$ for inlet and outlet air stram at evaporator, subsequently. With air velocity 1.5 $\mathrm{m} / \mathrm{s}$, the COP of the system was 3.7. Water collected from AWH was 1.1 litres/hour with energy consumption of $1.24 \mathrm{kWh}$. The AWH could be considered as a water harvester with value of specific energy of $1.13 \mathrm{kWh} /$ litre and MHI of 0,2.
\end{abstract}

Keywords: water harvester; refrigeration; energy consumption; $\mathrm{COP}$; $\mathrm{MHI}$

\section{PENDAHULUAN}

Saat ini ketersediaan air minum merupakan suatu tantangan yang harus diselesaikan. Beberapa teknologi telah diteliti untuk layak menjadi sumber air yang memungkinkan untuk daerah tandus [1]. Pemanenan air dari udara atmosfer adalah pendekatan yang dikembangkan dengan cara mendinginkan udara agar air yang terkandung dalam udara lembab terkondensasi.

Beberapa peneliti telah menyelidiki hubungan antara produksi air dan kondisi udara di atmosfer, yaitu suhu, tekanan dan kelembaban relatif atau absolut, untuk proses kondensasi udara lembab. Milani dkk. mengusulkan hubungan antara kondisi udara di atmosfer di bagian masuk komponen pendingin dan jumlah air yang dapat dikondensasi dengan thermoelectric coolers (TECs) [2], dengan nilainya sebesar US\$ 82 per kilo liter air yang dihasilkan atau setara dengan Rp. 1.230 per liter. Terdapat evaluasi jumlah air minum yang dapat diperoleh oleh sisetm pendingin dengan tenaga surya [3]. Namun, penelitian ini tidak menyelidiki bagaimana parameter operasi sistem pendingin mempengaruhi produksi air.

Penelitian lain menyatakan bahwa nilai aliran udara berpengaruh signifikan kuantitas air yang terkondensasi [4], [5], yang memperkirakan kuantitas air yang terkondensasi untuk aliran udara yang berbeda untuk sistem pendinginnya.

Pemanenan air dari atmosfer (atmospheric water harvester - AWH) yang didesentralisasi adalah solusi untuk berbagai tantangan dalam proses pemurnian air. Jika daya input disuplai dari sumber energi bersih (misalnya matahari, angin, pasang surut, panas bumi), AWH akan menjadi sumber daya air terbarukan dan berkelanjutan karena: i) kelembaban atmosfer diperbarui secara alami melalui penguapan dari laut, dan ii) proses AWH tidak menghasilkan efek samping atau produk samping yang berbahaya bagi lingkungan. Terdapat beberapa studi literatur yang fokus pada proses dan fungsi dari sistem AWH untuk panen air [6-9]. Namun, sebagian besar studi ini ada pada kelayakan proses, terutama di daerah tropis dan pesisir yang biasanya suhu dan tingkat kelembaban tinggi [10-13]. Salah satu teknologi yang pertama menangani pengambilan air dari atmosfer adalah pada tahun 1947 [14]. Sebuah alat diciptakan yang terdiri dari sistem saluran vertikal dan miring di bawah tanah untuk mengumpulkan air dari atmosfer dengan mendinginkan udara lembab ke suhu di bawah titik embunnya. Gad dkk. [15] melaporkan pengambilan air menggunakan cairan desikan melalui penyerapan serta menggunakan desikan padat melalui proses adsorpsi-desorpsi. Milani et al. $[12,16]$ mengklasifikasikan metode dehumidifikasi udara menjadi tiga kategori utama: i) kondensasi pada permukaan pendingin, ii) penyerapan menggunakan bahan desikan, dan iii) pemisahan gas menggunakan membran. Sistem tersebut dapat digunakan untuk AWH untuk mengirimkan 5,2 liter air per hari di Sydney, Australia.

Scrivani dan Bardi [6] menghitung konsumsi energi AWH dengan mempertimbangkan efisiensi untuk setiap komponen utama di dalam sistemnya. Berdasarkan perhitungan mereka, konsumsi energi per unit pembangkit air bervariasi antara 2.256,54 
$\mathrm{kWh} / \mathrm{m}^{3}$ di Tripoli hingga 7.910,04 $\mathrm{kWh} / \mathrm{m}^{3}$ di Rayack, keduanya di Lebanon. Habeebullah [7] menghitung hasil air AWH dalam iklim di Jeddah Arab Saudi, yang relatif panas dan lembab Berdasarkan data yang dilaporkan, estimasi bulanan rata-rata hasil air per luasan alat pemanen air (evaporator) coil selama Agustus dan Februari adalah 509 dan $401 \mathrm{~kg} / \mathrm{m}^{2}$.

Gido dkk. [17] memperkenalkan indeks baru, yaitu indeks pemanenan kelembaban (moisture harvesting index-MHI) sebagai rasio panas laten kondensasi terhadap total panas transfer di alat pemanen air, untuk mengevaluasi fungsi dan efektivitas biaya AWH. Mereka menyimpulkan bahwa MHI <0,3 mewakili kondisi yang tidak menguntungkan untuk AWH. Untuk daerah tropis, daya pengumpulan air sebesar $0,23 \mathrm{~kW} / \mathrm{L}$.

Lekouch dkk. [18] berfokus pada pengumpulan kabut alami dari atmosfer di wilayah kering Maroko barat daya. Embun air dikumpulkan dengan menggunakan kondensor embun pasif standar dan air kabut dikumpulkan dengan menggunakan pengumpul kabut planar. Mereka juga mensimulasikan hasil embun dan melaporkan bahwa potensinya $0,3-18,1$ liter per $\mathrm{m}^{2}$ permukaan pengumpulan, dari Mei hingga Oktober (total) pada 15 kota-kota di Maroko.

Sharan dkk. [8] juga mempelajari hasil embun dari besi galvanis bergelombang, tidak berinsulasi, di barat laut pedesaan India. Mereka memperkirakan bahwa untuk lebar atap yang umum $100-300 \mathrm{~m}^{2}$ di wilayah barat laut India, air embun dapat menyediakan 600-1800 L selama musim kemarau musim (akhir September hingga awal Mei) saat air sangat dibutuhkan oleh penduduk.

Bergmair dkk. [9] menganalisis membran yang difasilitasi AWH menggunakan model matematika. Mereka menunjukkan bahwa daerah yang hangat dan lembab, penggunaan membran selektif untuk memekatkan uap air sebelum pendinginan dan kondensasi akan secara signifikan mengurangi konsumsi energi sistem AWH. Berdasarkan indeks yang diperoleh, sekitar $40 \%$ sampai dengan $68 \%$ penghematan konsumsi energi per unit volume air yang dipanen tercapai.

Saat ini, alat pemanen air dengan sistem pendingin atau sistem refrigerasi telah banyak diteliti untuk mengetahui efektifitas penyediaan air. Beberapa peralatan alat pemanen air tipe ini juga telah dipabrikasi untuk keperluan pemanenan air dari udara atmosfer. Aplikasi hasil-hasil riset yang diuraikan di bagian pendahuluan telah dikreasikan menjadi alat yang dipabrikasi menggunakan komponen standar peralatan pendingin untuk keperluan komersial yang didasarkan pada keperluan bisnis semata. Jalur cost-effective atau efisiensi alat masih belum tereksplorasi secara luas. Karenanya, kegiatan riset ini mengusulkan pengembangan alat pemanen air berbasis sistem refrigerasi kompresi uap.
Efisiensi alat pemanen air ditentukan oleh biaya energi spesifik yang merupakan rasio antara biaya energi dikonsumsi oleh alat pemanen air persatuan kilogram air yang dihasilkan. Efisiensi dilakukan dengan mendisain sistem pemanen air yang tepat. Targetnya adalah mendapatkan desain prototipe pemanen air yang memiliki kapasitas optimal (efisiensi tertinggi). Karenanya, penentuan spesifikasi komponen pembangun sistem refrigerasi untuk alat pemanen air perlu diriset.

Penelitian dilakukan untuk mengembangkan prototipe alat pemanen air yang efisien dan hemat energi sehingga nantinya dapat menghasilkan air bersih sebanyak 1 liter/jam.

\section{METODE PENELITIAN}

Untuk mencapai target riset, maka peta jalan kegiatan ini melingkupi beberapa tahap, yaitu: tahap ke-1 adalah pengembangan alat pemanen air berbasis sistem refigerasi kompresi uap, dan tahap ke-2 scaleup alat pemanen air. Kesemua tahapan dapat dilihat pada Gambar 1.

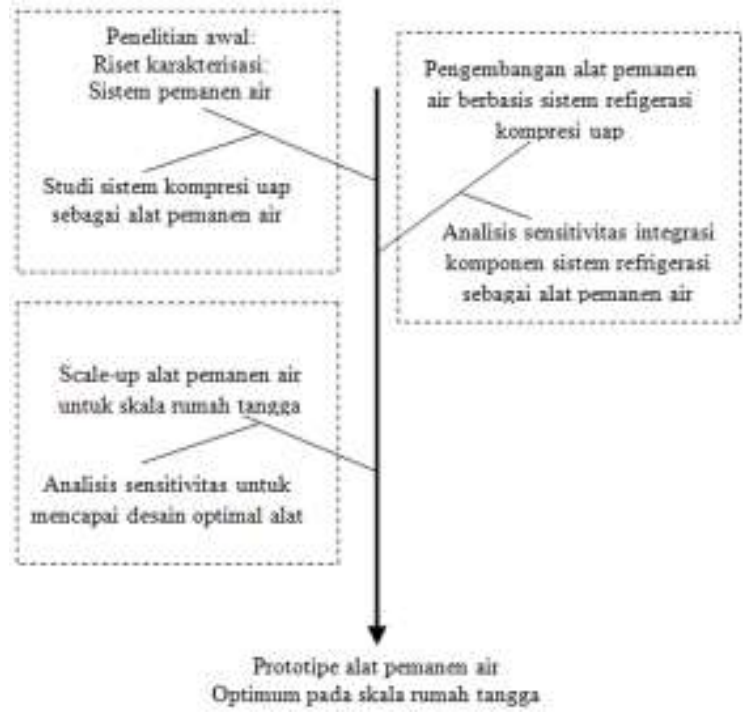

Gambar 1. Tahapan Penelitian

Riset yang dilakukan saat ini adalah riset pada tahap ke-1 yaitu pengembangan alat pemanen air berbasis sistem refigerasi kompresi uap.

\section{Desain dan Pabrikasi Alat Pemanen Air Berbasis Refrigerasi Sistem Kompresi Uap}

Desain peralatan alat pemanen air yang akan dibuat terdiri atas komponen-komponen: evaporator, kondensor, kompresor, katup ekspansi, dan inverter. Skema alat dapat dilihat pada Gambar 2. Alat pemanen air dilengkapi dengan instrumen antara lain:

- $\quad$ Refrigerant gauge, untuk mengukur temperatur dan tekanan refrigeran.

- Termohygrometer, untuk mengukur temperatur dan kelembaban relatif udara.

- $\quad$ Anemometer, untuk mengukur kecepatan udara. 
- Infra-red thermometer, untuk mengukur temperatur permukaan evaporator dan kondenser.

- Kontroller, yang berfungsi untuk mengendalikan putaran fan berdasarkan kindisi suhu dan kelembaban udara.

- Timbangan digital, untuk mengukur berat air yang terkondensasi.

Instrumen refrigerant gauge dan termometer diinstal di bagian masuk (inlet) dan keluar (outlet) setiap komponen. Kecepatan udara diukur pada bagian masuk evaporator.

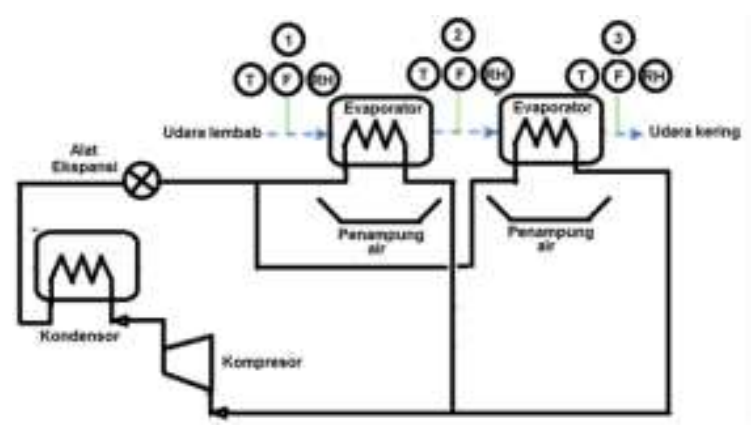

Gambar 2. Skema Alat Pemanen Air

\section{Uji Performa Alat Pemanen Air}

Uji performa alat pemanen air dilakukan untuk mengetahui perubahan nilai parameter setiap komponen ketika beban evaporator berubah. Perubahan beban evaporator dikarenakan adanya perubahan suhu dan kelembaban udara yang mengalir melintas evaporator. Variabel dalam penelitian ini adalah:

- Variabel kontrol: suhu setting sistem yaitu $0{ }^{\circ} \mathrm{C}$ dan kecepatan fan sebesar 1,5 m/s.

- Variabel bebas: suhu udara $\left(\mathrm{T},{ }^{\circ} \mathrm{C}\right)$ dan kelembaban relatif udara $(\mathrm{RH}, \%)$ inlet evaporator

- Variabel terikat: daya listrik $(\mathrm{kW})$, suhu suhu udara $\left(\mathrm{T},{ }^{\circ} \mathrm{C}\right)$ dan kelembaban relatif udara $(\mathrm{RH}$, $\%$ ) outlet evaporator, tingkat keadaan refrigerant.

\section{Prosedur Penelitian}

Setelah peralatan selesai dipabrikasi kemudian dilakukan pengujian fungsional alat pemanen air dengan langkah sebagai berikut:

- Menyalakan kompresor.

- Pastikan bacaan pressure gauge tidak mengalami perubahan siknifikan saat kondisi tunak.

- Pastikan bacaan termometer tidak mengalami perubahan siknifikan saat kondisi tunak.

Dan langkah pengambilan data dilakukan dalam 2 (dua) tahap meliputi pra-riset dan riset utama. Pengambilan data untuk pra-riset dilakukan sebagai berikut:

1. Menjalankan sistem alat pemanen air sampai suhu refrigeran terindikasi stabil dan direncanakan dengan suhu $0^{\circ} \mathrm{C}$.
2. Catat waktu yang diperlukan untuk mencapai kondisi tersebut dengan interval waktu setiap 1 menit.

Selanjutnya untuk pengambilan data riset utama dilakukan mulai dari keadaan pendingin (air conditioning) bekerja dengan stabil (tunak) sehingga data yang diambil valid. Prosedur pengambilan data pengujian adalah sebagai berikut:

- Mulai

- Mengatur temperatur sesuai rencana dan tunggu hingga sistem alat pemanen air dalam kondisi tunak (steady).

- Catat hasil pengamatan instrumen pengukuran seperti temperatur dan kelembaban udara, kecepatan udara, temperatur dan tekanan refrigeran, dan daya kompresor.

Pencatatan dilakukan pada sebuah table seperti tersaji pada Tabel 1 dan Tabel 2.

Tabel 1. Lembar Pencatatan Data Sisi Udara

\begin{tabular}{|c|c|c|c|c|c|c|c|c|c|}
\hline \multirow{2}{*}{$t$} & \multicolumn{2}{|c|}{ INLET } & \multicolumn{2}{|c|}{ OUTLET } & \multicolumn{4}{|c|}{ Kecepuan Udura } & \multirow{2}{*}{$\begin{array}{l}\text { Jumlah } \\
\text { air } \\
\text { (gram) }\end{array}$} \\
\hline & $\mathrm{A}(\mathrm{e})$ & $2 \mathrm{H}(\%)$ & $\mathrm{T}(\mathrm{CC})$ & $\mathrm{RH}(\mathrm{S})$ & Ftak 1 & Fitk 2 & Ftak 3 & Titk 4 & \\
\hline 1 & & & & & & & & & \\
\hline 2 & & & & & & & & & \\
\hline 3 & & & & & & & & & \\
\hline 4 & & & & & & & & & \\
\hline 5 & & & & & & & & & \\
\hline & & & & & & & & & \\
\hline
\end{tabular}

Tabel 2. Lembar Pencatatan Data Sisi Refrigeran

\begin{tabular}{|c|c|c|c|c|c|c|c|c|c|}
\hline \multirow{2}{*}{ t } & \multicolumn{2}{|c|}{$\begin{array}{c}\text { DNEET } \\
\text { EVAPORATOR. }\end{array}$} & \multicolumn{2}{|c|}{$\begin{array}{c}\text { OUTLET } \\
\text { EVAFORATOR. }\end{array}$} & \multicolumn{2}{|c|}{$\begin{array}{c}\text { DNLET } \\
\text { CONDENSER. }\end{array}$} & \multicolumn{2}{|c|}{$\begin{array}{l}\text { OUTLET } \\
\text { CONDENGER. }\end{array}$} & \multirow{2}{*}{\begin{tabular}{|c|} 
DAYA \\
W \\
(Watt)
\end{tabular}} \\
\hline & $\mathrm{I}(\mathrm{C})$ & $\mathrm{P}\left(\mathrm{kg} \mathrm{cm}^{2}\right)$ & $\mathrm{T}(\mathrm{C})$ & $\mathrm{P}\left(\mathrm{kg} / \mathrm{cm}^{2}\right)$ & $\mathrm{I} / \mathrm{C}$ & $P\left(\mathrm{gg}^{\prime}\left(\mathrm{cm}^{2}\right)\right.$ & $\mathrm{I}(\mathrm{C})$ & $\mathrm{P}\left(\mathrm{kg} \mathrm{Cm}^{2} \mathrm{~T}\right)$ & \\
\hline 1 & & & & & & & & & \\
\hline 2 & & & & & & & & & \\
\hline 3 & & & & & & & & & \\
\hline 4 & & & & & & & & & \\
\hline 5 & & & & & & & & & \\
\hline & & & & & & & & & \\
\hline
\end{tabular}

\section{HASIL DAN PEMBAHASAN}

Data dalam eksperimen ini meliputi data pada aliran udara, data pada refrigeran, dan data pada permukaan pipa. Data tersebut diplot, dianalisis dan didiskusikan, yang hasilnya tersaji pada setiap subbab berikut ini.

\section{Analisis Suhu pada Evaporator}

Suhu pada evaporator meiputi suhu refrigerant dalam pipa evaporator dan suhu dinding pipa evaporator. Suhu refrigerant dalam pipa evaporator merupakan suhu evaporasi refrigerant yang diukur menggunakan refrigerant gauge, sedangkan suhu pipa adalah suhu yang diukur pada permukaan pipa inlet dan outlet pada evaporator-1 dan evaporator-2. Profil suhu tersebut dapat dilihat pada Gambar 3. 


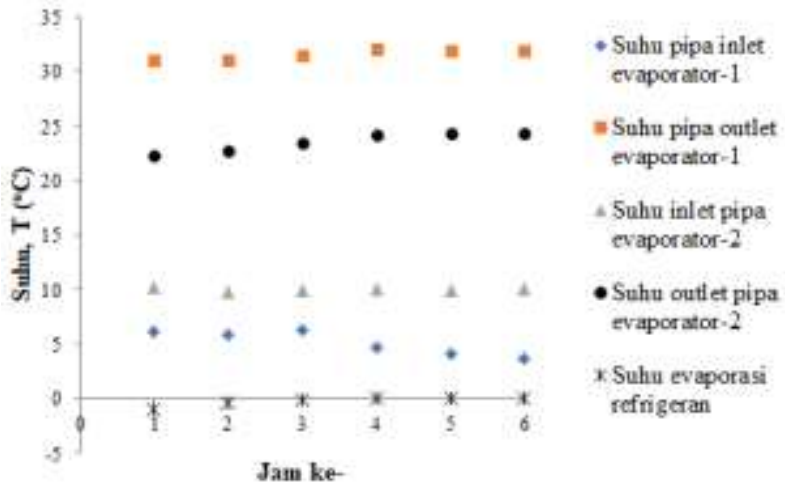

Gambar 3. Profil Suhu Evaporator-1 dan Evaporator-2

Suhu refrigerant berada pada rentang $-3{ }^{\circ} \mathrm{C}$ sampai dengan $0{ }^{\circ} \mathrm{C}$, sedangkan suhu permukaan pipa pada inlet evaporator-1 berfluktuasi pada rentang $3{ }^{\circ} \mathrm{C}$ $-6{ }^{\circ} \mathrm{C}$ dan pada inlet evaporator- 2 adalah $9{ }^{\circ} \mathrm{C}-10$ ${ }^{\circ} \mathrm{C}$. Perbedaan suhu inlet permukaan pipa pada kedua evaporator ini diduga karena adanya perbedaan laju alir massa refrigerant inlet evaporator. Laju alir masa refigeran dalam pipa evaporator-1 lebih besar daripada dalam evaporator-2. Perbedaan ini merupakan efek dari sensitivitas sistem dalam merespon beban pendinginan (cooling load) di evaporator.

\section{Analisis Aliran Udara Melintas Evaporator}

Aliran udara melintas evaporator mengalami perubahan suhu dan kelembaban relatif (relative humidity - RH). Profil perubahan suhu dan RH tersebut dapat dilihat pada Gambar 4.

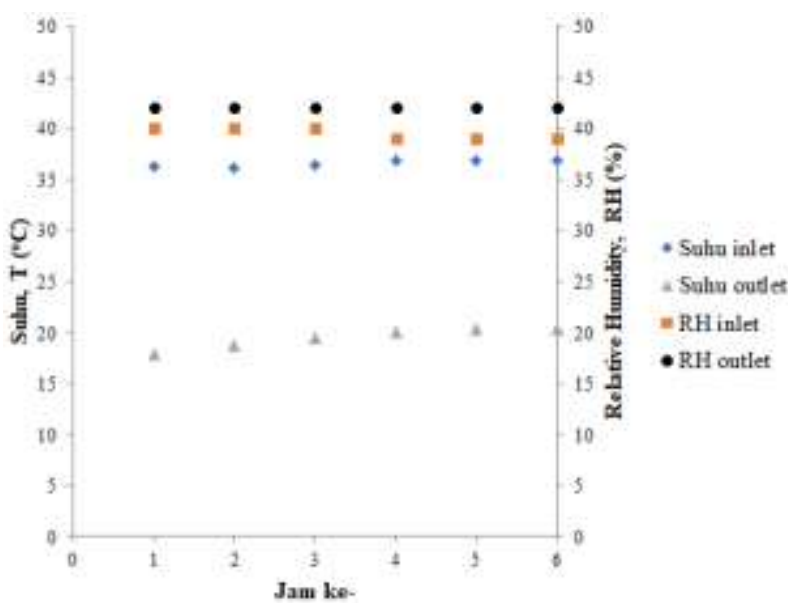

Gambar 4. Profil Suhu dan RH Aliran Udara

Gambar 4 memperlihatkan profil suhu dan $\mathrm{RH}$ yang diambil dari jam 9.00 sampai dengan jam 15.00. Selama 6 jam, suhu dan RH inlet dan outlet evaporator tidak mengalami fluktuasi yang siknifikan. Suhu rata-rata inlet dan outlet udara berturut-turut adalah $36,6{ }^{\circ} \mathrm{C}$ dan $19,5^{\circ} \mathrm{C}$. memiliki nilai cenderung tetap kondisi tunak (steady state). Demikian juga dengan nilai RH yang memiliki nilai
40\% pada kondisi inlet dan $42 \%$ pada kondisi outlet. Penurunan suhu tersebut logis karea ketika melintas evaporator udara mengalami proses pendinginan.

Perubahan tingkat keadaan udara melintas evaporator digambarkan pada diagram psikrometri yang dapat dilihat pada Gambar 5. Kondisi inlet evaporator dinotasikan dengan nomer 1 , sedangkan outlet dengan nomer 2. Dari keadaan 1 ke keadaan 2, aliran udara mengalami perubahan suhu $d r y$-bulb dan suhu wet-bub, yang diindikasikan dengan perubahan RH. Selain itu, tingkat energi aliran udara dari dan outlet mengalami penurunan yang diindikasikan dengan penurunan entalpi udara.

Saat udara berkontak dengan dinding pipa evaporator, yang bersuhu lebih rendah dari suhu kondensasi (dew point) udara, terdapat sebagian partikel udara yang melingkupi pipa dan membentuk suatu lapis batas (boundary layer). Lapisan tersebut mengalami penurunan suhu (dari titik 1 ke 2) hingga mencapai suhu kondensasi. Kemudian lapisan udara tersebut mengalami kondensasi (dari titik 2 ke 3) dan membentuk lapisan tipis kondensat di permukaan pipa. Di waktu berikutnya, terdapat sejumlah partikel udara yang berkontak dengan lapisan kondensat dan mengalami penurunan suhu hingga suhu kondensasi. Partikel tersebut berkondensasi sehingga terjadi akumulasi kondensat di permukaan pipa. Pada jumlah tertentu, lapisan akumulasi kondensat tersebut jatuh sebagai bintik air. Patikel udara bersuhu rendah yang tidak terkondensasi akan berdifusi dengan partikel lain dalam aliran udara sehingga menyebabkan suhu total udara turun.

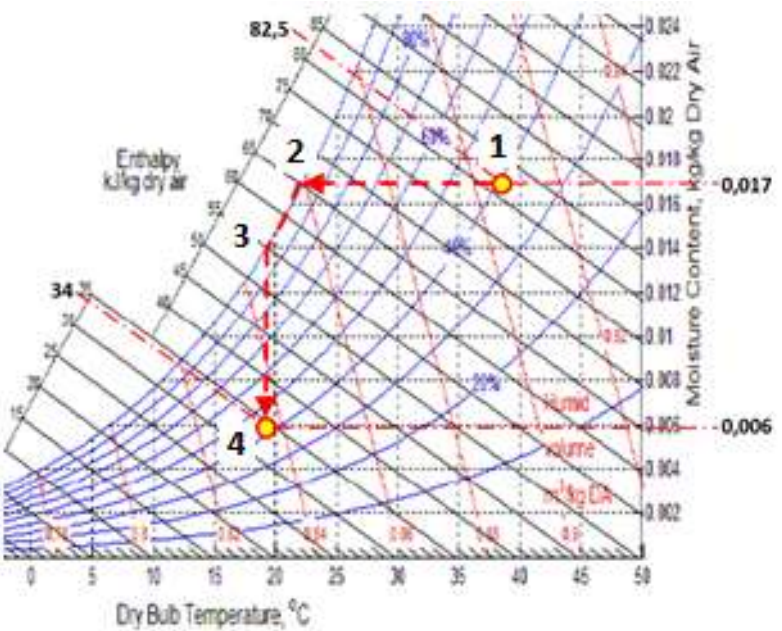

Gambar 5. Proses Pendinginan Udara Melintas Evaporator

Gambar 5 juga menunjukkan bahwa moisture harvesting index-MHI) yang merupakan rasio panas laten kondensasi terhadap total panas transfer di alat pemanen air, terbaca sebagai rasio beda entalpi ( $\square$ h) dari 2-3 dan 1-4. Nilai dari MHI adalah 0,2. Nilai ini lebih kecil dari 0,3. Menurut Gido dkk [17], kondisi ini mewakili kondisi yang tidak menguntungkan untuk AWH. 
Interaksi antara udara dan dinding pipa evaporator menyebabkan terjadinya perpindahan massa dan kalor dari udara ke dinding pipa. Distribusi suhu udara dan pipa evaporator akibat perpindahan massa dan kalor dapat dilihat pada Gambar 6.

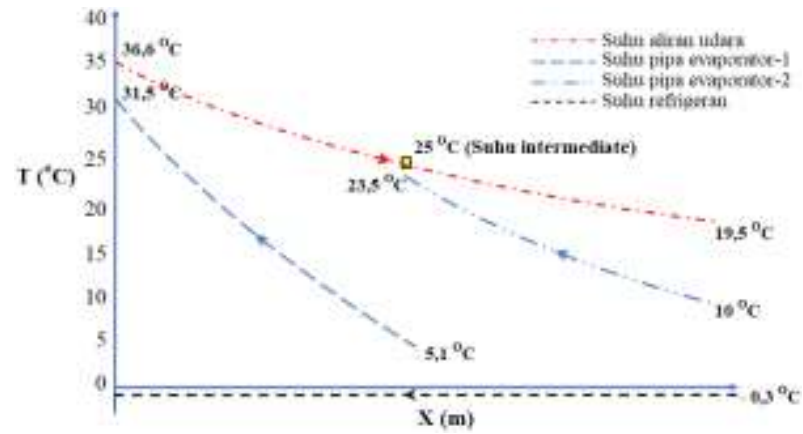

Gambar 6. Profil Suhu dan RH Aliran Udara

Gambar 6 memperlihatkan bahwa terdapat perbedaan suhu antara inlet dan outlet pada pipa evaporator-1 $\left(\square \mathrm{T}_{\mathrm{pev}, 1}\right)$ sebesar $26{ }^{\circ} \mathrm{C}$ dan pada evaporator-2 ( $\left.\square \mathrm{T}_{\mathrm{pev}, 2}\right)$ sebesar $13,5^{\circ} \mathrm{C}$. Di sisi aliran udara, suhu intermediate (suhu udara keluar evaporator-1 atau masuk evaporator-2) diestimasi sebesar $25{ }^{\circ} \mathrm{C}$. Dengan demikian, perbedaan suhu inlet dan outlet udara di evaporator-1 dan evaporator2 berturut-turut adalah $11,6^{\circ} \mathrm{C}$ dan $5,5^{\circ} \mathrm{C}$.

\section{Analisis Tingkat Keadaan Refrigeran}

Sistem refrigerasi pada AWH mengaplikasikan dua evaporator yang disusun secara seri yang masing-masing dilengkapi dengan coil ekspansi, sebuah kondensor, sebuah kompresor 1 tingkat, dan menggunakan media pendingin refrigeran R-404A. Data suhu dan tekanan di setiap tingkat keadaan refrigerant yang mengalir dalam siklus refrigerasi AWH diplot pada diagram tekananentalpi ( $p$-h diagram) yang dapat dilihat pada Gambar 7.

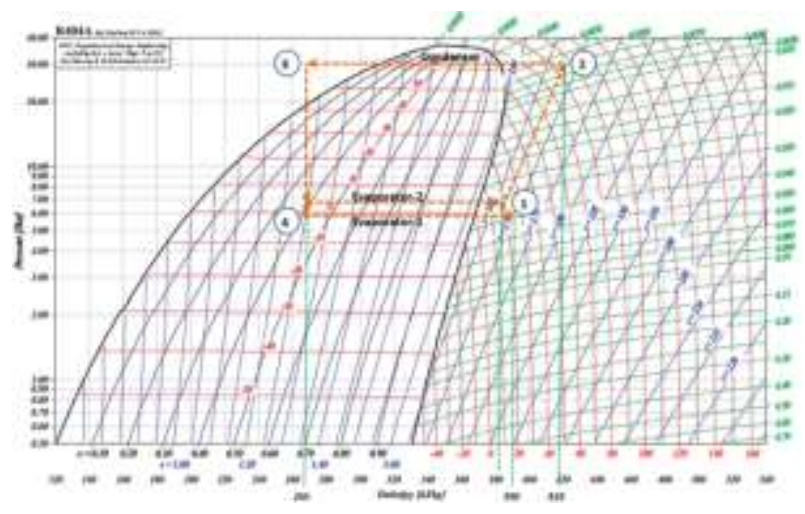

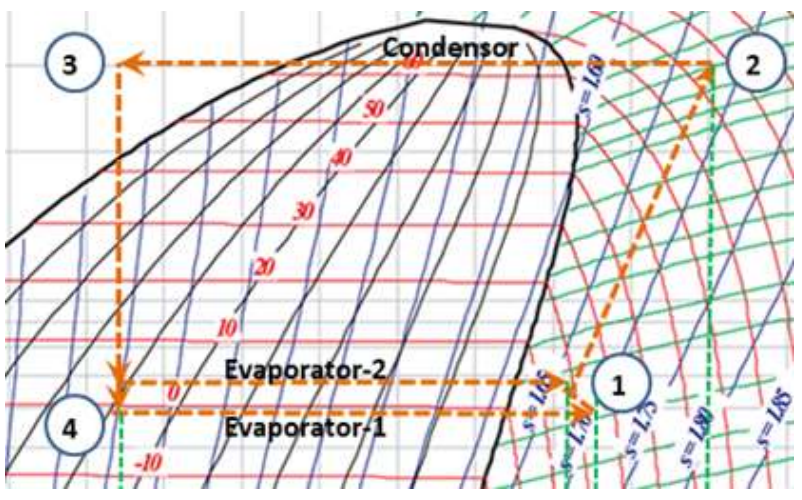

Gambar 7. Tingkat Keadaan Refrigeran R-404A dalam Sistem Refrigerasi AWH

Gambar 7 menunjukkan bahwa refrigerant bersirkulasi dalam siklus tertutup dengan urutan tingkat keadaan 1-2-3-4. Refrigeran masuk kedalam kompresor pada keadaan uap panas lanjut (superheated vapor) sehingga aman bagi kompresor. Namun, derajad panas lanjut $\left(\square \mathrm{T}_{\mathrm{SH}}\right)$ sebesar $15{ }^{\circ} \mathrm{C}$ lebih besar dari aturan praktis (rule of thumb) yaitu 5 ${ }^{\circ} \mathrm{C}$. Hal ini diduga pengaplikasian dua buah evaporator menyebabkan luas permukaan kontak antara pipa evaporator dan udara menjadi lebih besar sehingga refrigerant menerima beban kalor lebih besar yang menyebabkan suhu keluar evaporator tinggi. Didi sisi lain, hal ini menguntungkan karena udara mengalami proses pendinginan lebih besar.

Kalor yang dilepas oleh udara ketika melintas evaporator merupakan beban pendinginan (cooling load) yang dikalkulasi dengan dengan persamaan 1 :

$q_{u d}=\dot{m}_{u d} x c p_{u d} x\left(T_{u d, i n}-T_{u d, o u t}\right)$

Keterangan:

$q_{u d}=$ Kalor yang dilepas oleh udara $(\mathrm{kW})$

$\dot{m}_{u d}=$ Laju alir massa udara (kg.s)

$c_{\text {pud }}=$ Kalor jenis udara $=1 \mathrm{~kJ} / \mathrm{kg} . \mathrm{K}$

$T_{u d, i n}=$ Suhu udara di inlet evaporator $\left({ }^{\circ} \mathrm{C}\right)$

$T_{u d, \text { out }}=$ Suhu udara di outlet evaporator $\left({ }^{\circ} \mathrm{C}\right)$

Data eksperimen dan dimensi fan evaporator diberikan sebagai berikut:

$\mathrm{v}_{\mathrm{ud}}=$ kecepatan udara $=1,5 \mathrm{~m} / \mathrm{s}$

$\mathrm{d}_{\text {fan }}=$ diameter fan $=25 \mathrm{~cm}=0,25 \mathrm{~m}$

Laju alir massa udara dikalkulasi menggunakan persamaan 2:

$\dot{m}_{u d}=\rho_{u d} \times v_{u d} \times A_{\text {fan }}$

$\square$ ud adalah densitas udara $\left(1,2 \mathrm{~kg} / \mathrm{m}^{3}\right)$, dan $\mathrm{A}_{\text {fan }}$ adalah luas penampang aliran udar dari fan $\left(0,049 \mathrm{~m}^{2}\right)$. Laju alir massa udara adalah:

$$
\begin{aligned}
\dot{m}_{u d} & =\rho_{u d} \times v_{u d} \times A_{\text {fan }} . \\
& =1,2 \mathrm{~kg} / \mathrm{m}^{3} \times 1,5 \mathrm{~m} / \mathrm{s} \times 0,049 \mathrm{~m}^{2} \\
& =0,088 \mathrm{~kg} / \mathrm{s}
\end{aligned}
$$


Beban pendinginan di setiap evaporator dikalkulasi dengan persamaan 1. Dengan demikian, beban pendinginan di evaporator-1 adalah:

$$
\begin{aligned}
\text { qud,evap- } 1 & =0,088 \mathrm{~kg} / \mathrm{s} \times 1 \mathrm{~kJ} / \mathrm{kg} \cdot \mathrm{K} \times(36,6-25) \\
& =1,02 \mathrm{~kW}
\end{aligned}
$$

dan beban pendinginan di evaporator- 2 adalah:

qud,evap-2 $=0,088 \mathrm{~kg} / \mathrm{s}$ x $1 \mathrm{~kJ} / \mathrm{kg} . \mathrm{K} \times(25-19)$

$$
=0,49 \mathrm{~kW}
$$

Dengan menerapkan kesetimbangan energi dan dengan asumsi beban pendinginan dipindahkan ke refrigeran tanpa kehilangan kalor (heat loss), maka laju alir massa refrigeran di setiap evaporator dapat ditentukan. Kesetimbangan energi pada evaporator disajikan dengan persamaan 3 .

$\mathrm{q}_{\mathrm{ud}, \mathrm{evap}}=\mathrm{q}_{\mathrm{ref}}=\dot{m}_{\text {ref }} x\left(h_{\text {ref,out }}-x h_{\text {ref,in }}\right)$

Untuk menentukan laju alir refrigerant, maka persamaan 3 dimanipulasi menjadi:

$$
\dot{m}_{\text {ref }}=\frac{q_{u d, \text { evap }}}{\left(h_{\text {ref,out }}-x h_{\text {ref }, \text { in }}\right)}
$$

Kalkulasi laju alir masa di evaporator-1 dan evaporator-2 adalah:

$$
\begin{aligned}
& \dot{m}_{\text {ref,evap-1 }}=\frac{1,02 \mathrm{~kW}}{(390-265) \mathrm{kJ} / \mathrm{kg}}=8,172 \mathrm{~g} / \mathrm{s} \\
& \dot{m}_{\text {ref,evap }-2}=\frac{0,49 \mathrm{~kW}}{(380-265) \mathrm{kJ} / \mathrm{kg}}=4,262 \mathrm{~g} / \mathrm{s}
\end{aligned}
$$

Laju alir massa toal refrigerant sebesar 12,434 $\mathrm{g} / \mathrm{s}$ ini merupakan laju alir massa refrigerant yang mengalir dalam sistem. Kompresor memfasilitasi laju alir masa refrigeran ini untuk mempertahankan operasi sistem. Daya kompresi yang diwakili oleh perubahan tingkat keadaan refrigerant dari keaddan 1 ke keadaan 2 dikalkulasi dengan persamaan 4 .

$$
\begin{aligned}
\dot{w}_{\text {comp }} & =\dot{m}_{\text {ref }} x\left(h_{\text {comp,out }}-h_{\text {comp }, \text { in }}\right) \\
& =(12,434 / 1000) \mathrm{kg} / \mathrm{s} \times(418-385) \mathrm{kJ} / \mathrm{kg} \\
& =0,41 \mathrm{~kW}
\end{aligned}
$$

Coefisien of Performa (COP) sistem dikalkulasi dengan persamaan 5 .

$$
\begin{aligned}
& \text { COP }=\frac{q_{\text {evap }}}{w_{\text {comp }}} \\
& C O P=\frac{1,51 \mathrm{~kW}}{0,41 \mathrm{~kW}}=3,7
\end{aligned}
$$

Beberapa literatur menyatakan bahwa COP lebih besar dari 3 merupakan COP untuk kategori sistem yang baik.

Daya listrik input ke sistem terukur sebesar 1,24 kW. Daya ini digunakan untuk kelistrikan kompresor, fan evaporator dan kondensor, serta panel control, sehingga konsumsi energi listrik dalam satu jam sebesar 1,24 kWh. Air yang terkoleksi dari AWH ini adalah sebesar 1,1 liter per jam.

Energi spesifik merupakan konsumsi energi untuk menghasilkan 1 liter air. Dengan demikian, energi spesifik dikalkulasi menggunakan peramaan 6 .

$$
\begin{aligned}
\text { Energi spesifik } & =\frac{\text { konsumsi energi }}{\text { jumlah air terkoleksi }} \\
& =\frac{1,24}{1,1}=1,13 \mathrm{kWh} / \text { liter }
\end{aligned}
$$

Jika tarif dasar listrik yang berlaku sebesar Rp. 1.450 maka harga air yang diproduksi dari AWH per liter adalah Rp. 1.640. Nilai ini lebih tinggi dari AWH yang didesain dengan menggunakan thermoelectric coolers (TECs) oleh Milani dkk, yaitu sebesar Rp. 1.230 per liter [2].

\section{KESIMPULAN}

Penambahan evaporator pada AWH yang menggunakan sistem refrigerasi kompresi uap menunjukkan nilai COP yang tinggi. Namun, energi spesifik sebesar $1,13 \mathrm{kWh} /$ liter merupakan nilai yang tinggi jika dibandingkan dengan sistem yang menggunakan thermoelectric coolers (TECs). Sistem AWH pada riset ini memiliki nilai MHI sebesar 0,2, yang mewakili kondisi yang tidak menguntungkan untuk AWH. Namun demikian, AWH yang dikembangkan ini dapat dipertimbangkan untuk desain hibrid AWH-Dehumidifier yang mampu memproduksi air dan udara kering bersuhu rendah yang keluar dari evaporator, sebagai udara pengering untuk bahan yang sensitif terhadap suhu tinggi.

\section{UCAPAN TERIMA KASIH}

Terima kasih diucapkan kepada Sekolah Vokasi Universitas Diponegoro yang telah memberikan hibah dana Non-APBN pada riset ini, dan kepada tim teknisi yang telah memberikan dukungan pada pengembangan alat AWH ini.

\section{DAFTAR PUSTAKA}

1. J.J. Bogardi, D. Dudgeon, R. Lawford, E. Flinkerbusch, A. Meyn, C. Pahl-Wostl, K. Vielhauer, C. Vörösmarty, 2012, Water security for a planet under pressure: interconnected challenges of a changing world call for sustainable solutions, Curr. Opin. Environ. Sustain 4 (1) pp. 35-43.

2. D. Milani, A. Abbas, A. Vassallo, M. Chiesa, D. A. Bakri, 2011, Evaluation of using thermoelectric coolers in a dehumidification system to generate freshwater from ambient air, 
Chemical Engineering Science 66 pp. 24912501.

3. W.A. Jury, H.J. Vaux, 2007, The emerging global water crisis: managing scarcity and conflict, Adv. Agron. 95 (7) pp. 1-76.

4. Ariwibowo, D., \& Darmanto, S., 2020, Refrigeration system based-dehumidifier, IOP Conference Series: Materials Science and Engineering (Vol. 845, No. 1, p. 012039). IOP Publishing.

5. D. Milani, A. Qadir, A. Vassallo, M. Chiesa, A. Abbas, 2014, Experimentally validated model for atmospheric water generation using a solar assisted desiccant dehumidification system, Energy Build. 77 pp. 236-246.

6. A. Scrivani, U. Bardi, 2008, A study of the use of solar concentrating plants for the atmospheric water vapour extraction from ambient air in the Middle East and Northern Africa region, Desalination 220 (1-3) pp. 592-599.

7. B.A. Habeebullah, 2009, Potential use of evaporator coils for water extraction in hot and humid areas, Desalination 237 (1-3) pp. 330 345.

8. G. Sharan, D. Beysens, I. MilimoukMelnytchouk, 2007, A study of dew water yields on galvanized iron roofs in Kothara (North-West India), J. Arid Environ. 69 (2) pp. 259-269.

9. D. Bergmair, S.J. Metz, H.C. De Lange, A.A. van Steenhoven, 2014, System analysis of membrane facilitated water generation from air humidity, Desalination 339 (1) pp. 26-33.

10. B. Hellstorm, 1969, Potable water extracted from the air report on laboratory experiments, Hydrology 9 pp. 1-19.

11. L. Avenue, Provence U. De, 1996, Water recovery from dew, J. Hydrol. 182 pp. 19-35.

12. D. Milani, A. Qadir, A. Vassallo, M. Chiesa, A. Abbas, 2014, Experimentally validated model for atmospheric water generation using a solar assisted desiccant dehumidification system, Energy Build. 77 pp. 236-246.

13. D. Beysens, I. Milimouk, V. Nikolayev, M. Muselli, J. Marcillat, 2003, Using radiative cooling to condense atmospheric vapor: a study to improve water yield, J. Hydrol. 276 (1-4) pp. $1-11$.

14. V. Tygarinov, 1947, An equipment for collecting water from air. Patent No. 69751.

15. H. Gad, A. Hamed, I. El-Sharkawy, 2001, Application of a solar desiccant/collector system for water recovery from atmospheric air, Renew. Energy 22 (4) pp. 541-556.

16. D. Milani, 2011, Modelling Framework of Solar Assisted Dehumidification System to Generate Freshwater from 'Thin Air,' (Master Thesis), University of Sydney.
17. B. Gido, E. Friedler, D.M. Broday, 2016, Assessment of atmospheric moisture harvesting by direct cooling, Atmos. Res. 182 pp. 156-162.

18. I. Lekouch, K. Lekouch, M. Muselli, A. Mongruel, B. Kabbachi, D. Beysens, 2012, Rooftop dew, fog and rain collection in southwest Morocco and predictive dew modeling using neural networks, J. Hydrol. 448-449 pp. 60-72.

19. ANSI/AHRI Standard 210/240, Standard, 2012, Performance Rating of Unitary AirConditioning \& Air-Source Heat Pump Equipment.

20. ASHRAE Standard16, 2016, Method of Testing for Rating Room Air Conditioners and Packaged Terminal Air Conditioners.

21. ANSI/ASHRAE Standard 128-, 2011, Method of Rating Portable Air Conditioners.

22. 〈https://weatherspark.com/averages/31262/StPetersburg-Florida-United-States $\rangle$.

23. 〈https://weatherspark.com/averages $\rangle$. 